\title{
Effect of Cooling Slope and Manganese on the Microstructure of Hypereutectic Al-Si Alloy with $2 \% \mathrm{Fe}$
}

\author{
Lu Li $i^{a}$, Rongfeng Zhou ${ }^{a, b *}$, Dehong L $u^{a}$, Yehua Jiang ${ }^{a}$, Rong Zhou ${ }^{a}$ \\ ${ }^{a}$ College of Materials Science and Engineering, Kunming University of Science and Technology - KUST, \\ 650039, Kunming, Yunnan, China \\ ${ }^{b}$ Research Center for Analysis and Measurement, \\ Kunming University of Science and Technology - KUST, 650039, Kunming, Yunnan, China
}

Received: August 17, 2013; Revised: October 25, 2013

\begin{abstract}
The effect of cooling slope (CS) on the microstructure of hypereutectic Al-22Si-2Fe (\% w/w) alloys with $0 \%, 0.99 \%$, and $1.36 \% \mathrm{Mn}$ were studied. The results showed that primary Si particles (PSPs), needle-like Fe phases, coarse fishbone-shaped $\alpha-\mathrm{Al}_{15}\left(\mathrm{Fe}, \mathrm{Mn}_{3} \mathrm{Si}_{2}\right.$ phases, and eutectic $\mathrm{Si}$ could be refined. With such a CS process, the intermetallic compounds in the alloys with different $\mathrm{Mn} / \mathrm{Fe}$ ratios were examined with an optical microscope, scanning electron microscope, and X-ray diffraction. Moreover, the acicular $\delta-\mathrm{Al}_{4}(\mathrm{Fe}, \mathrm{Mn}) \mathrm{Si}_{2}$ and blocky $\alpha-\mathrm{Al}_{15}(\mathrm{Fe}, \mathrm{Mn})_{3} \mathrm{Si}_{2}$ phases were analyzed by transmission electron microscopy.
\end{abstract}

Keywords: hypereutectic Al-Si alloys, cooling slope, Mn/Fe ratio, intermetallic compounds

\section{Introduction}

Hypereutectic $\mathrm{Al}-\mathrm{Si}$ alloys have low thermal expansion coefficients, excellent wear resistance, and high hardness. Thus, they have been widely used to make wear resistant components in the automotive industry. However, their low toughness and poor ductility, which are caused by harmful morphologies of primary Si particles (PSPs), such as coarse polygonal, star-like, and other irregular shapes, limit the wider application of these alloys. The addition of phosphorous or phosphorous compound to the melt can promote nucleation of PSPs for refining PSPs that can obtain AlP particles ${ }^{1}$. However, the refining effect of phosphorous or phosphorous compound on PSPs is limited due to the agglomeration of AIP particles ${ }^{2}$. According to the experiment of predecessors, the equivalent diameter of PSPs modified by phosphorous is not less than $40 \mu \mathrm{m}^{[3]}$. In recent years, the semi-solid processing of hypereutectic $\mathrm{Al}$-Si alloys has been investigated widely. Research shows that PSPs can be refined and their morphology improved by preparing hypereutectic $\mathrm{Al}-\mathrm{Si}$ alloys semi-solid slurries using cooling slope (CS) casting ${ }^{4,5}$.

To replace cast iron with hypereutectic Al-Si alloys, the hypereutectic Al-Si alloys must still have the originally desired mechanical properties. The addition of Fe to the hypereutectic $\mathrm{Al}-\mathrm{Si}$ alloys can form $\mathrm{Fe}$ inter-metallic compounds, which can improve thermal stability. In contrast, $\mathrm{Fe}$ compounds such as $\alpha-\mathrm{Al}_{4} \mathrm{FeSi}_{2}$ and $\beta-\mathrm{Al}_{5} \mathrm{FeSi}$ phases present as acicular structures which result in inferior tensile strength ${ }^{6}$. Some researchers have proved that the morphologies of intermetallic compounds could be modified and presented acicular, Chinese-script shape, fishbone shaped, and block-like respectively with varying contents of $\mathrm{Mn}$ is added to the cast $\mathrm{Al}-\mathrm{Si}-\mathrm{Fe}$ alloys under conventional

*e-mail: zhourfchina@hotmail.com casting condition ${ }^{7-9}$. According to the literatures, PSPs and coarse Fe-rich phases also could be refined by spray deposition or ultrasonic vibration process ${ }^{10-12}$. Comparing these methods, the cooling process has shorter process flow and lower operating cost. However, systemic researches on the influence and mechanism of Mn addition to the solidification microstructure of such alloys by CS casting have not been reported.

The present study aimed to investigate the effect of segmented cooling plates on the microstructure of hypereutectic $\mathrm{Al}-22 \mathrm{Si}-2 \mathrm{Fe}(\% \mathrm{w} / \mathrm{w})$ alloys with $0 \%$, $0.99 \%$, and $1.36 \% \mathrm{Mn}$. The effect of $\mathrm{Mn} / \mathrm{Fe}$ on the CS-cast microstructure of hypereutectic Al-Si alloys was also examined. In addition, the transformations of Fe-rich phases during CS casting process in hypereutectic Al-Si alloys were also discussed.

\section{Experimental Work}

Hypereutectic Al-22Si-xFe-yMn alloys were prepared from pure $\mathrm{Al}, \mathrm{Si}-7 \%$ Fe master alloy, and $75 \% \mathrm{Mn}$ agent in a $6.5 \mathrm{~kW}$ resistance furnace. The process was as follows: pure $\mathrm{Al}$ was heated to $850^{\circ} \mathrm{C}$, blocky Si-7\% Fe master alloy at a grain size of 1 to $2 \mathrm{~cm}$ diameter wrapped in aluminium foil was rapidly immersed into the molten aluminium in batches and stirred once every twenty minutes until the master alloy had completely melted. Afterwards, the Mn agent with $75 \% \mathrm{Mn}$ was crushed to a particle diameter of between 1 and $2 \mathrm{~cm}$ in diameter before its addition to the molten $\mathrm{Al}-$ 22Si-xFe alloy. Once the Mn agent had melted, the melt was stirred and insulated for 30 minutes. In the following, phosphorus wrapped with aluminium foils was pressed into the metal and stirred. After being held for 20 minutes, $\mathrm{C}_{2} \mathrm{Cl}_{6}$ 
was added for degassing, then the slag was skimmed off. The solidus and liquidus of the three alloys neared 575 and $780{ }^{\circ} \mathrm{C}$, respectively. Hence, after being held for a further 10 minutes, the melt was cooled to $800^{\circ} \mathrm{C}$ and poured into a high purity graphite crucible $0.06 \mathrm{~m}$ in diameter and $0.2 \mathrm{~m}$ deep at room temperature by CS technology. CS casting was employed using segmented cooling plates (Figure 1). The chemical composition of the Al-22Si-xFe-yMn alloys studied is listed in Table 1. Due to the material sticking to the surface of traditional integral cooling plates after CS casting, the integral plate was replaced with segmented plates. The lower segmented plate was made of graphite because of the poor wettability between graphite and molten aluminium. Solidified shell layers barely formed on the surface of two plates even though molten alloy flowed through the lower graphite plate after passing through the upper plate. CS casting was carried out in a sealed steel box. Argon at 99.9\% purity was pumped in to prevent oxidation during processing. According to previous experiments, fine, regular shaped PSPs could be obtained when the upper steel plate was $30^{\circ}$ and the lower graphite plate was $50^{\circ}$, besides, the effective length required of each plate was $0.3 \mathrm{~m}$.

After cooling to room temperature, the melt in the high purity graphite crucible was removed and cut into cylindrical slugs of $0.02 \mathrm{~m}$ in diameter and $0.03 \mathrm{~m}$ height. The CS casting microstructures of the samples were revealed by etching with $0.5 \%$ hydrofluoric acid. The polished and etched specimens were examined with an optical microscope

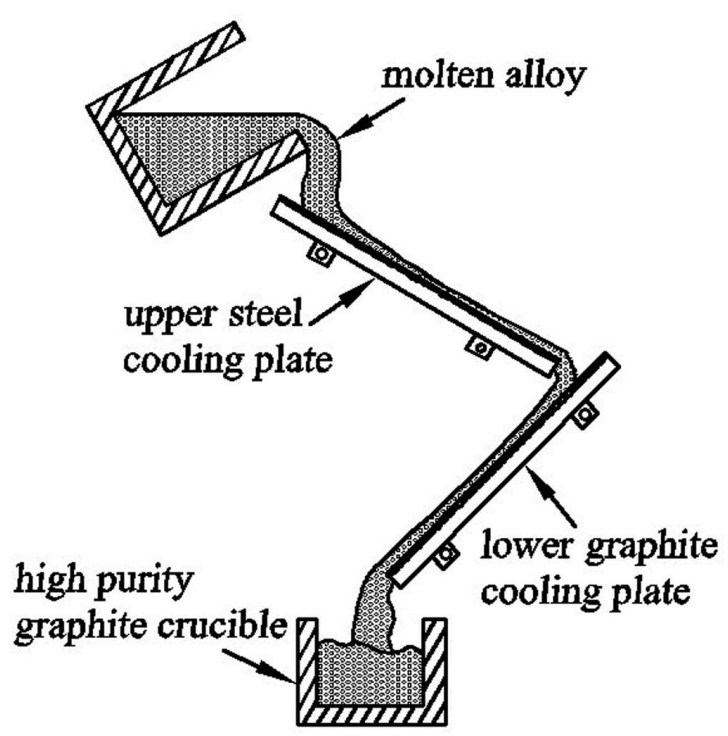

Figure 1. CS casting unit.

Table 1. Chemical composition of the experimental alloys (\% w/w).

\begin{tabular}{cccccc}
\hline Alloy & Si & Fe & Mn & Al & $\mathbf{M n} / \mathbf{F e}$ \\
\hline A0 & 22.34 & 1.90 & 0 & balance & 0 \\
A1 & 22.58 & 1.91 & 0.99 & balance & 0.52 \\
A2 & 22.77 & 1.93 & 1.36 & balance & 0.70 \\
\hline
\end{tabular}

(Leico), scanning electron microscope (SEM), energy spectrum (EDS) analysis system (XL30ESEM-TMP, Philips Co.), and X-ray diffraction (XRD) (D/max-3B, Ricoh Co.), while the solidus and liquidus were evaluated using a simultaneous thermal analyser (NETZSCH STA 499F3). The TEM analysis of Fe-rich phases was carried out using a Tecnai G2 F30 S-TWIN transmission microscopy operated at an acceleration voltage of $300 \mathrm{kV}$.

\section{Results and Discussion}

\subsection{The influence of segmented cooling plates on alloy morphology}

Figure 2 shows the as-cast and CS microstructures of A0, $\mathrm{A} 1$, and A2 alloys. The as-cast microstructures of A0, A1, and A2 alloys are shown in Figures 2a, c, and e, respectively. The CS cast microstructures of A0, A1, and A2 alloys are shown in Figures 2b, d, and f. As shown in Figure 2a, the as-cast microstructure of A0 alloy comprises of grey PSPs, white $\alpha$-Al, a black acicular microstructure, and lamellar eutectic Si. Almost all the $\alpha$-Al phases are formed around PSPs $(45 \pm 10 \mu \mathrm{m}$ equivalent spherical diameter). PSPs exhibit different morphologies such as coarser polygons, and other irregular shapes. It can be seen that the black acicular microstructure in Figure $2 \mathrm{a}$ is Fe intermetallic compounds at $100 \mu \mathrm{m}$ in length. Lamellar eutectic Si phases are uniform distributed in the microstructure. Figure $2 b$ shows CS cast microstructure of A0 alloy, compared with the PSPs in Figure 2a, the equivalent diameter of PSPs that present as block-like is reduced $(30 \pm 10 \mu \mathrm{m})$, and the number of PSPs per unit area is increased in Figure 2b. In addition, the number of black acicular Fe phases also is increased, and the length of Fe phases is reduced to $70 \mu \mathrm{m}$. It is worth mentioning that eutectic $\mathrm{Si}$ was refined by cooling slope process to present a fibrous morphology. The as-cast microstructure of A1 alloy is shown in Figure 2c, the equivalent diameter of PSPs is $50 \pm 10 \mu \mathrm{m}$. Compared with Figure 2a, the number of black needle-like Fe intermetallic compounds has been decreased, and their length is reduced to $70 \mu \mathrm{m}$. With Mn addition to the alloy, dark grey fishbonelike and block-like Fe-bearing compounds appear in the microstructure. The length of the entire fishbone-like Fe-bearing compound was measured at $200 \mu \mathrm{m}$, with a width of $40 \mu \mathrm{m}$. PSPs and needle-like Fe intermetallic compounds in the CS cast microstructure of A1 alloy were refined to a certain extent. The dark grey block-like compounds that surround PSPs, instead of coarser fishbone-like structures, appear in the CS cast microstructure of A1 alloy (at an $\mathrm{Mn} / \mathrm{Fe}$ ratio of 0.52). Figures $2 \mathrm{e}$ and $\mathrm{f}$ show the as-cast and CS-cast microstructures of A2 alloy, respectively. Comparing two casting methods, the equivalent diameter of PSPs is reduced to $30 \mu \mathrm{m}$, and the refinement induced by this CS casting method is apparent. When the $\mathrm{Mn} / \mathrm{Fe}$ ratio is increased to 0.7 (A2 alloy), there are no acicular Fe intermetallic compounds in the CS-cast microstructure: they are present in the as-cast microstructure. The dark grey compounds are dendritic and irregular in the as-cast. Whereas the dark grey compounds are regular and polygonal in solidification microstructure after the CS process. 


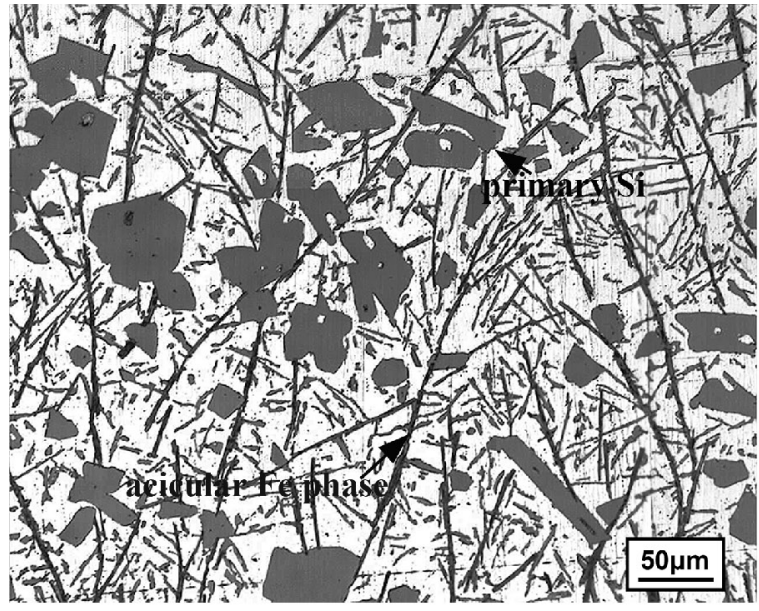

(a)

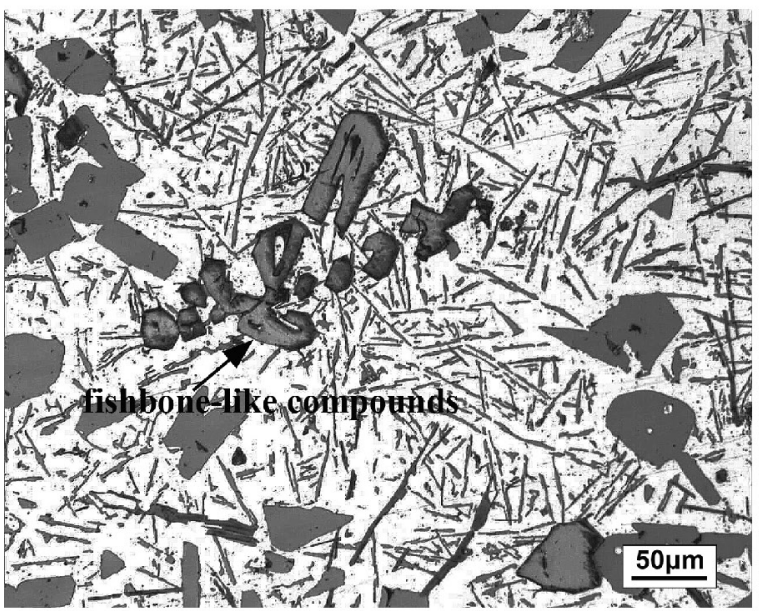

(c)

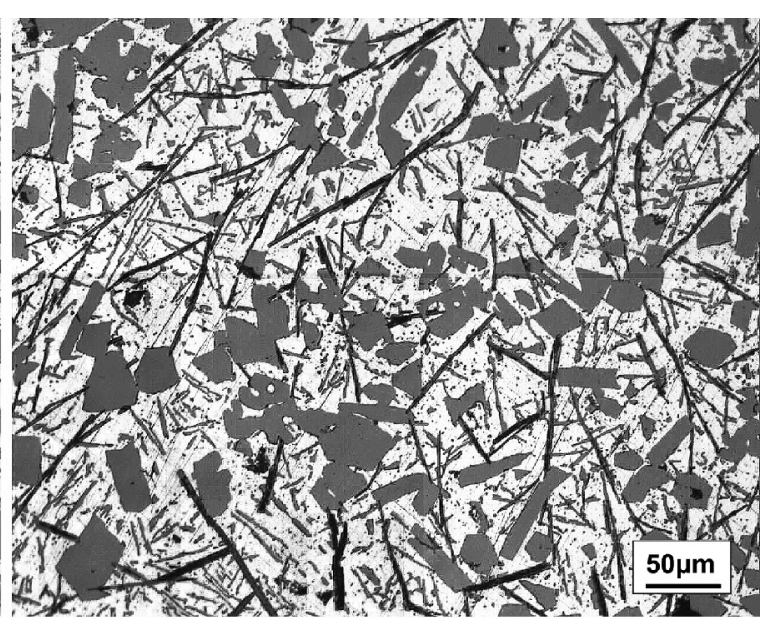

(b)

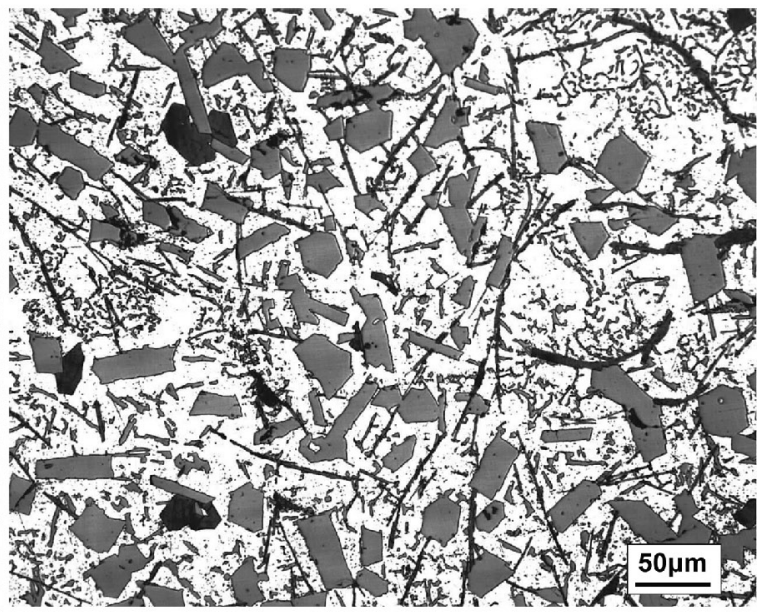

(d)

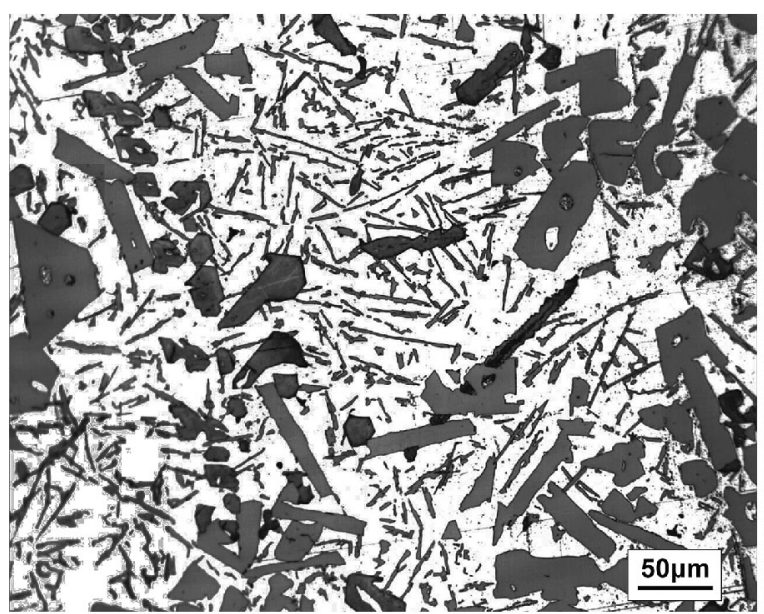

(e)

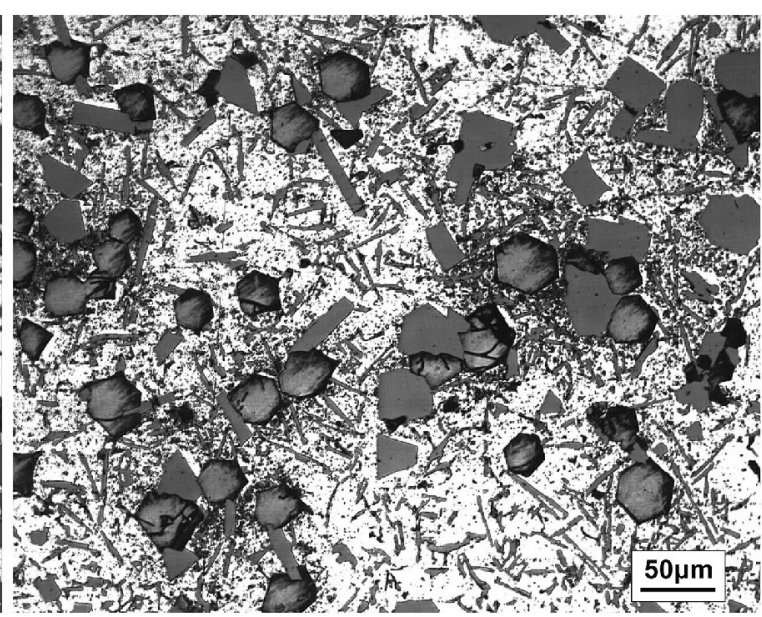

(f)

Figure 2. (a) As-cast microstructure of A0 alloy; (b) CS cast microstructure of A0 alloy; (c) As-cast microstructure of A1 alloy; (d) CS cast microstructure of A1 alloy; (e) As-cast microstructure of A2 alloy; (f) CS cast microstructure of A2 alloy.

Under the effect of gravity, the dynamic solidification process of the liquid melt occurred on the surfaces of the cooling plates when the liquid melt flowed through the surfaces of the cooling plates. The growth of PSP was anisotropic due to the $\mathrm{Si}$ atoms' greater diffusion. Only under conditions of rapid solidification and high undercooling to increase the nucleation rate, could the preferred orientation growth be inhibited whilst refining the microstructure. Thanks to the strong cooling action of the cooling slope plates, the PSPs' diameter by CS casting decreased relative 
to that obtained by conventional casting. By CS casting, coarser fishbone-shaped intermetallic compounds were developed in the shape of regular polygons or granules due to the shear force between the cooling plates and the melt and the homogenization of the molten solute. Therefore, intermetallic compounds were formed the blocky structure of Figures $2 \mathrm{~d}$ and $\mathrm{f}$ under the effect of the cooling plates. Umezawa et al. ${ }^{13}$ indicated that hypereutectic Al-18Si alloy with an $\mathrm{Mn} / \mathrm{Fe}$ ratio of 0.84 under the effect of sloped cooling plates, formed fishbone-shaped intermetallic compounds which could be improved to form blocky structures in the final solidification microstructure.

\subsection{The influence of $M n / F e$ ratio on the $C S$-cast microstructure of hypereutectic Al-Si-xFe- yMn alloy}

Figure $3 \mathrm{a}$ implies that the A0 alloy contains phases of $\alpha$-Al, PSP, $\delta-\mathrm{Al}_{4} \mathrm{FeSi}_{2}$, and $\beta-\mathrm{Al}_{5} \mathrm{FeSi}$. As shown in Figure $3 \mathrm{~b}$, the equivalent diameter of PSPs is between 30 and $40 \mu \mathrm{m}$, acicular Fe phases with length of $100 \mu \mathrm{m}$. The $\alpha-\mathrm{Al}$ phases are distributed between the microstructures of PSPs and eutectic Si. According to EDS analysis of the acicular intermetallic compound and the composition thereof, its molecular formula was inferred to be $\mathrm{Al}_{3.80} \mathrm{FeSi}_{2.47}$, which is close to that of the $\delta-\mathrm{Al}_{4} \mathrm{FeSi}_{2}$ phase. Based on related studies $^{14}$, metastable $\delta$ - $\mathrm{Al}_{4} \mathrm{FeSi}_{2}$ phase can be transformed to stable $\beta-\mathrm{Al}_{5} \mathrm{FeSi}$ through a peritectic reaction at a low cooling rate. However, this reaction was restricted by the high cooling rate of cooling plates and high purity graphite crucible. Therefore, long acicular intermetallic compounds mainly comprise of $\delta-\mathrm{Al}_{4} \mathrm{FeSi}_{2}$ phases in $\mathrm{CS}$ casting $\mathrm{A} 0$ alloy.

Figure 4 shows the influence of increasing $\mathrm{Mn} / \mathrm{Fe}$ ratio on the CS-cast microstructures of $\mathrm{Al}-22 \mathrm{Si}-\mathrm{xFe}-\mathrm{yMn}$ alloys. Figure 4a shows a BSE micrograph of CS-cast A1 alloy $(\mathrm{Mn} / \mathrm{Fe}=0.52)$ : acicular $\mathrm{Fe}$ phases at a length of about $100 \mu \mathrm{m}$ are present in the microstructure, bright white compounds attach to PSPs show block-like, or irregular shapes. As the $\mathrm{Mn} / \mathrm{Fe}$ ratio increased to 0.70 , black particulate phases are PSPs with equivalent diameters of about $30 \mu \mathrm{m}$, while bright white polygon-shaped compounds at an equivalent diameter of $80 \mu \mathrm{m}$ attach to the PSPs. Besides, a large number of fine Chinese script-shaped or fishbone-shaped intermetallic compounds evenly distributed could be observed in the eutectic CS-cast microstructures of A2 alloy.

The CS casting alloys A1 and A2, with different Mn/ Fe ratios, were investigated by XRD. As shown in Figure 5, the results indicate that a number of different phases were

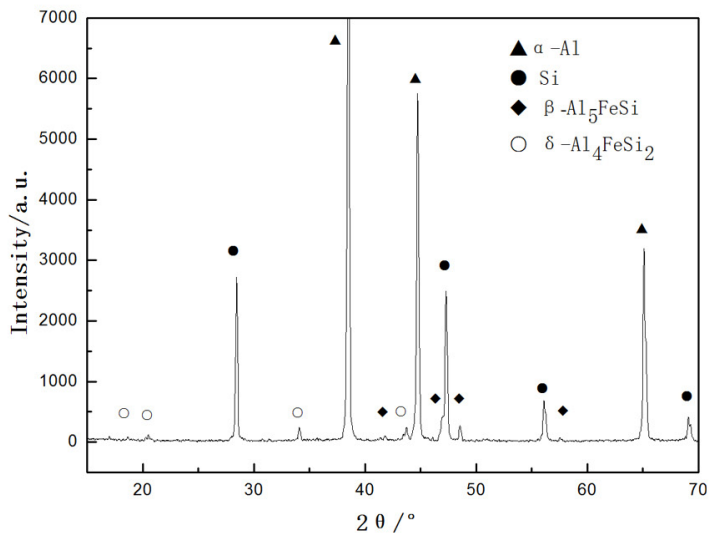

(a)

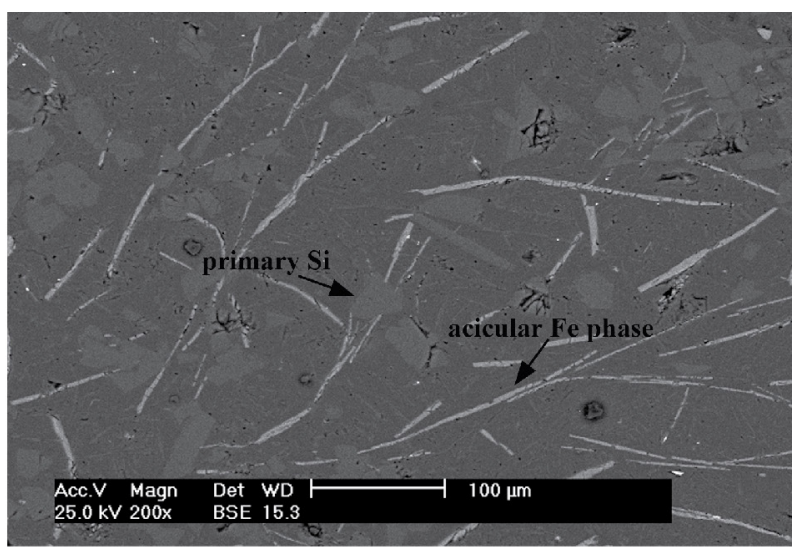

(b)

Figure 3. (a) XRD spectrum of CS casting A0 alloy; (b) Microstructures of CS casting A0 alloy: BSE microscopy.

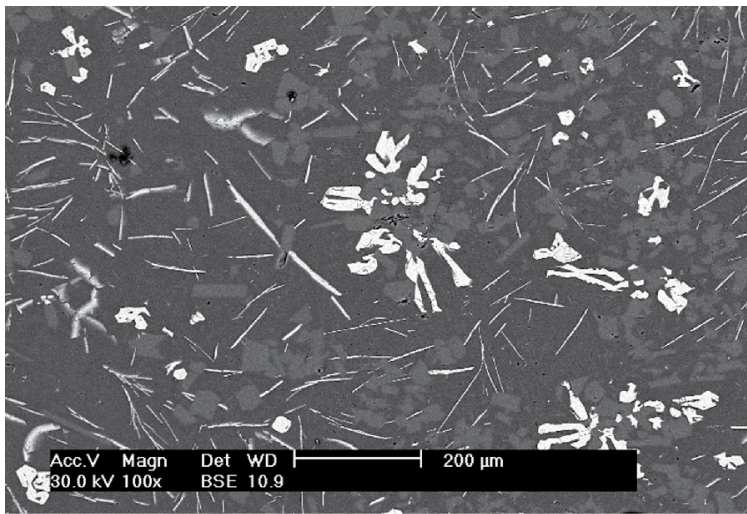

(a)

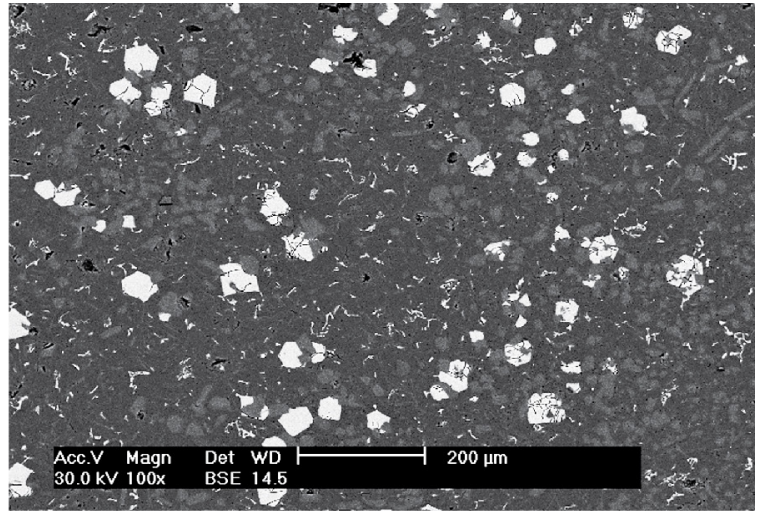

(b)

Figure 4. (a) BSE CS-cast micrographs of A1 alloy; (b) BSE CS-cast micrographs of A2 alloy. 
identified unambiguously in the two samples. There are diffraction waves for $\beta-\mathrm{Al}_{5}(\mathrm{Fe}, \mathrm{Mn}) \mathrm{Si}, \delta-\mathrm{Al}_{4}(\mathrm{Fe}, \mathrm{Mn}) \mathrm{Si}_{2}$ and $\alpha-\mathrm{Al}_{15}(\mathrm{Fe}, \mathrm{Mn})_{3} \mathrm{Si}_{2}$ as shown in the XRD spectrum for CS-cast A1 alloy. Compared to the XRD spectra for CS-cast A1 alloy, there is no clear diffraction wave for the $\beta-\mathrm{Al}_{5}(\mathrm{Fe}, \mathrm{Mn}) \mathrm{Si}$ phase as shown for the CS-cast A2 alloy. Only a diffraction wave for the $\delta-\mathrm{Al}_{4}(\mathrm{Fe}, \mathrm{Mn}) \mathrm{Si}_{2}$ phase could be found implying that a small amount of $\delta$ - $\mathrm{Al}_{4}(\mathrm{Fe}, \mathrm{Mn}) \mathrm{Si}_{2}$ phase remained in CS-cast $\mathrm{A} 2$ alloy albeit at a low concentration.

Figure 6a shows the acicular intermetallic compounds (labelled "A") in A1 alloy, polygon-shaped intermetallic compounds that are formed around to PSP (labelled "B") that can be observed in A2 alloy (shown in Figure 6b). The fine Chinese script-, or fishbone-shaped compounds (labelled "C") can be seen in the microstructure of A2 alloy (shown in Figure 6b). The energy spectrum results for the three compounds above are listed in Table 2. The results show that the compositions of the polygonal blocky compounds and Chinese script-shaped compounds are $\mathrm{Al}_{12.63}(\mathrm{Fe}, \mathrm{Mn})_{3} \mathrm{Si}_{2.33}$ and $\mathrm{Al}_{16.65}(\mathrm{Fe}, \mathrm{Mn})_{3} \mathrm{Si}_{1.85}$ respectively, which are similar to the $\mathrm{Al}_{15}(\mathrm{Fe}, \mathrm{Mn})_{3} \mathrm{Si}_{2}$ phase. While the acicular Fe phase's composition in the A1 alloy's microstructure is $\mathrm{Al}_{3.55}(\mathrm{Fe}, \mathrm{Mn}) \mathrm{Si}_{2.57}$, which is akin to the $\delta-\mathrm{Al}_{4}(\mathrm{Fe}, \mathrm{Mn}) \mathrm{Si}_{2}$ phase.

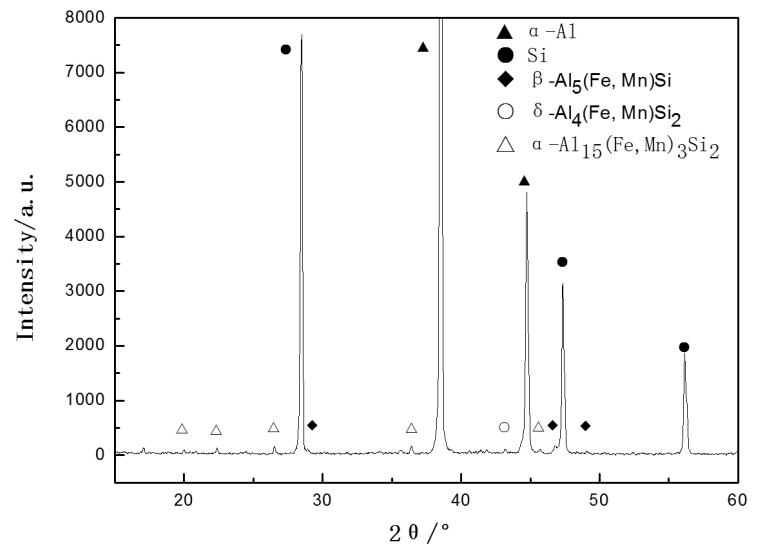

(a)

\subsection{TEM analysis for the Fe-rich phases in A2 alloy}

Figure 7 shows the TEM micrographs and their corresponding selected area diffraction patterns (SADPs) of A1 and A2 alloys. The bright-field TEM image of $\delta-\mathrm{Al}_{4}(\mathrm{Fe}, \mathrm{Mn}) \mathrm{Si}_{2}$ phase in $\mathrm{A} 1$ alloy, and the SADPs pattern taken from the phase are shown in Figure 7a. The SADP corresponds to tetragonal structure, which is the same as the lattice structure of $\delta-\mathrm{Al}_{4} \mathrm{FeSi}_{2}$ phase. According to these results, Mn can substitute $\mathrm{Fe}$ in the $\delta-\mathrm{Al}_{4} \mathrm{FeSi}_{2}$ lattice. The blocky $\mathrm{Al}_{15}(\mathrm{Fe}, \mathrm{Mn})_{3} \mathrm{Si}_{2}$ phase (the phase was stroked because the high voltage) and its SADP are shown in Figure 7b. Through the analysis of the SADP, $\mathrm{Al}_{15}(\mathrm{Fe}, \mathrm{Mn})_{3} \mathrm{Si}_{2}$ phases are identified with body centre cubic.

Table 2. Energy spectra of intermetallic compounds in CS cast $\mathrm{A} 1$ and $\mathrm{A} 2$ alloys.

\begin{tabular}{ccccc}
\hline Phase marked & Al (\%) & Si (\%) & Fe (\%) & Mn (\%) \\
\hline "A" & 49.86 & 36.12 & 09.69 & 04.34 \\
"B" & 70.35 & 1296 & 08.38 & 08.32 \\
"C" & 77.26 & 8.57 & 12.14 & 1.77 \\
\hline
\end{tabular}

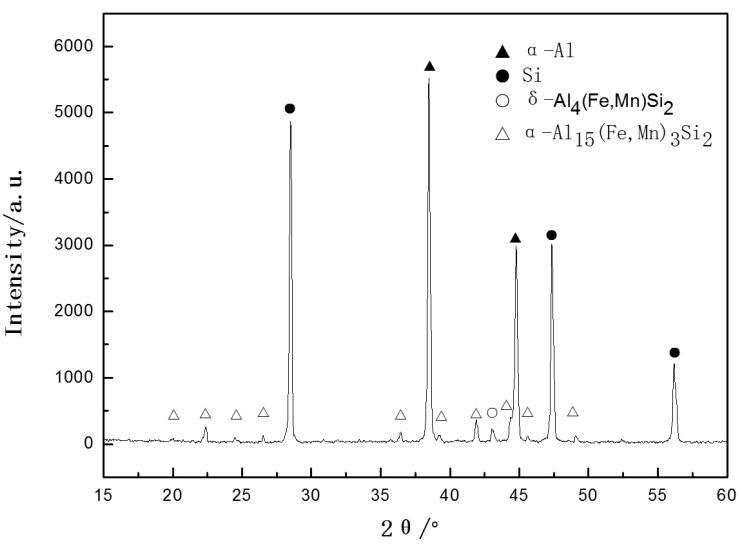

(b)

Figure 5. (a) XRD spectra of CS-cast A1 alloy; (b) XRD spectra of CS-cast A2 alloy.

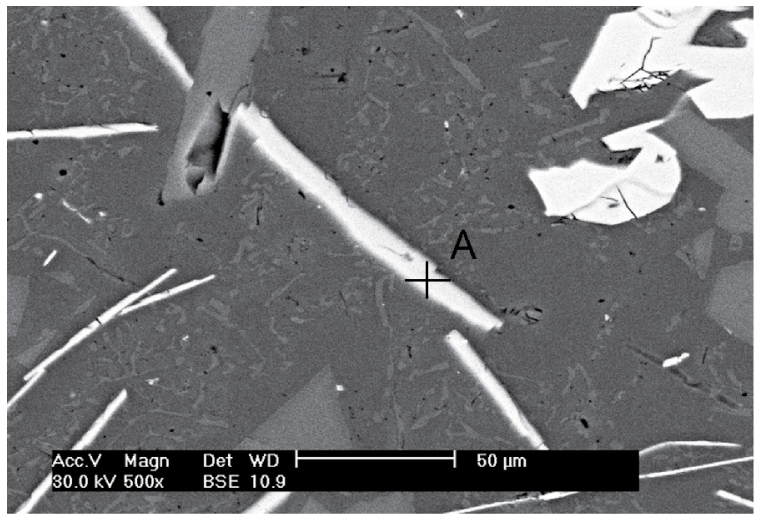

(a)

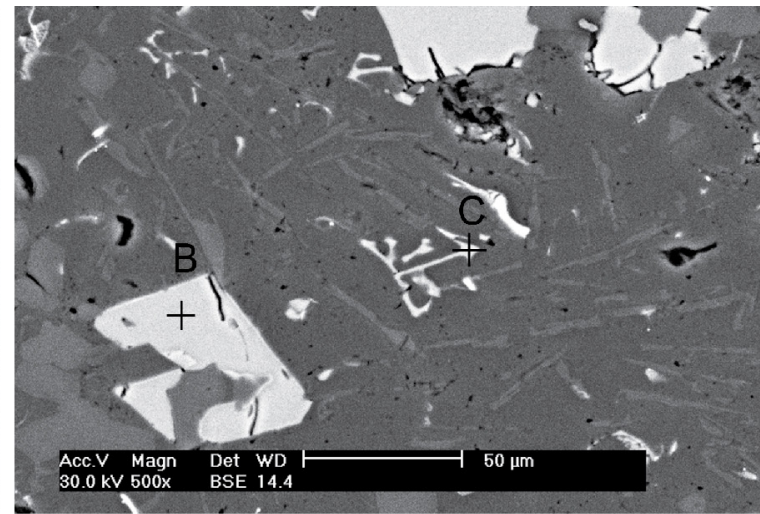

(b)

Figure 6. (a) Enlarged BSE micrograph of CS-cast A1 alloy; (b) Enlarged BSE micrograph of CS-cast A2 alloy. 


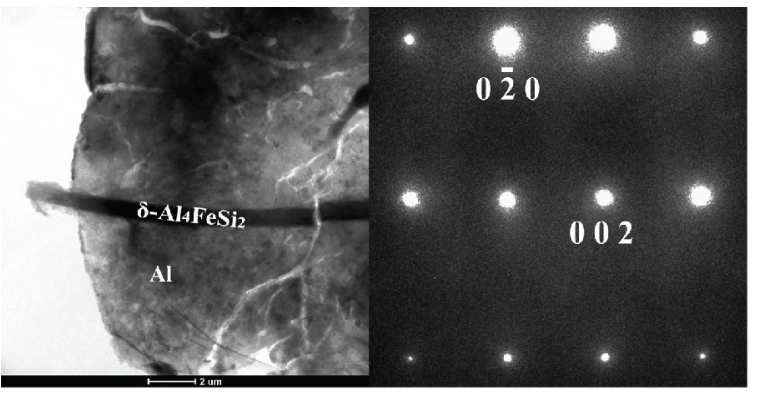

(a)

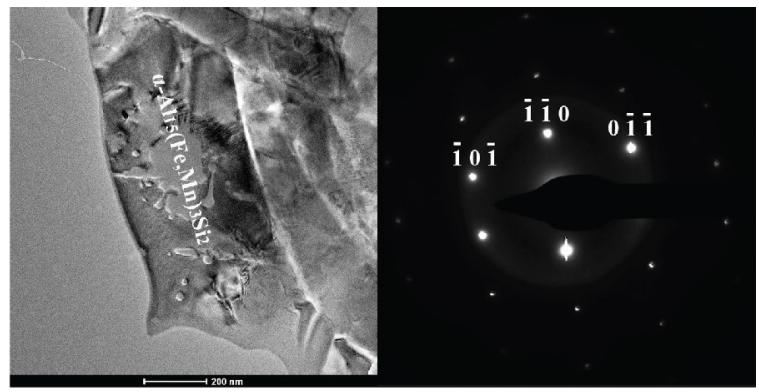

(b)

Figure 7. Bright-field TEM images of Fe-rich phases in A2 alloy: (a) SAPD of acicular $\delta-\mathrm{Al}_{4}(\mathrm{Fe}, \mathrm{Mn}) \mathrm{Si}{ }_{2}$ phase along the $\left[\begin{array}{llll}1 & 0 & 0\end{array}\right]$ zone axis; (b) SAPD of blocky $\alpha-\mathrm{Al}_{15}(\mathrm{Fe}, \mathrm{Mn})_{3} \mathrm{Si}_{2}$ phase along the $\left[\begin{array}{lll}-1 & 1 & 1\end{array}\right]$ zone axis.

\subsection{The transformations of Fe-rich phases during CS casting process}

According to the Al-Si-Fe ternary phase diagram ${ }^{15}$, the equilibrium solidification of high Si alloys with $2 \% \mathrm{Fe}$ starts with the formation of a primary $\mathrm{Si}$ phase followed by the formation of a $\delta-\mathrm{Al}_{4} \mathrm{FeSi}_{2}$ phase. The primary $\delta-\mathrm{Al}_{4} \mathrm{FeSi}_{2}$ phase can be transformed to stable $\beta-\mathrm{Al}_{5} \mathrm{FeSi}$ phase by a peritectic reaction at lower cooling rates and below $610{ }^{\circ} \mathrm{C}$. The addition of $\mathrm{Mn}$ to the solidification process - without reaction but with just replacement of atoms due to a low Mn content - lead to the coexistence of $\mathrm{Fe}$ and $\mathrm{Mn}$ atoms in the lattice of the $\delta$ phase $^{16}$. Therefore, the equilibrium solidification of high $\mathrm{Si}$ alloys with $\mathrm{Mn} / \mathrm{Fe}$ ratios of 0.52 started with a primary Si phase. As the solidification proceeded, the $\delta-\mathrm{Al}_{4}(\mathrm{Fe}, \mathrm{Mn}) \mathrm{Si}_{2}$ phase crystallised. Research by Huang et al. ${ }^{10}$ suggested that crystallised $\delta-\mathrm{Al}_{4}(\mathrm{Fe}, \mathrm{Mn}) \mathrm{Si}_{2}$ phases react with the liquid phase to produce an $\alpha-\mathrm{Al}_{15}(\mathrm{Fe}, \mathrm{Mn})_{3} \mathrm{Si}_{2}$ phase. Moreover, $\delta-\mathrm{Al}_{4}(\mathrm{Fe}, \mathrm{Mn}) \mathrm{Si}_{2}$ phases are involved in the peritectic reaction causing transformation to acicular $\beta-\mathrm{Al}_{5}(\mathrm{Fe}, \mathrm{Mn})$ $\mathrm{Si}$ phases below $610^{\circ} \mathrm{C}$. The remaining liquid phase is then solidified at its eutectic temperature, and a eutectic $\mathrm{Si}, \alpha-\mathrm{Al}$ and Chinese script-, or fishbone-shaped $\alpha-\mathrm{Al}_{15}(\mathrm{Fe}, \mathrm{Mn})_{3} \mathrm{Si}_{2}$ were precipitated in the quaternary eutectic reaction.

Hypereutectic Al-22Si with an $\mathrm{Mn} / \mathrm{Fe}$ ratio of 0.52 (A1 alloy), under the action of the cooling plates, entailed the crystallisation of a large amount of PSPs, followed by the formation of a $\delta-\mathrm{Al}_{4}(\mathrm{Fe}, \mathrm{Mn}) \mathrm{Si}_{2}$ phase. However, the strong cooling effect inhibited the transformation of metastable $\delta-\mathrm{Al}_{4}(\mathrm{Fe}, \mathrm{Mn}) \mathrm{Si}_{2}$ to $\alpha-\mathrm{Al}_{15}(\mathrm{Fe}, \mathrm{Mn})_{3} \mathrm{Si}_{2}$ while the $\delta-\mathrm{Al}_{4}(\mathrm{Fe}, \mathrm{Mn}) \mathrm{Si}_{2}$ that does not participate in the conversion was transformed to stable $\beta-\mathrm{Al}_{5}(\mathrm{Fe}, \mathrm{Mn}) \mathrm{Si}$ at temperatures below $610{ }^{\circ} \mathrm{C}$. The author measured the temperature at which the melt flowed out of cooling plates at $650{ }^{\circ} \mathrm{C}$, and the conversion from $\delta-\mathrm{Al}_{4}(\mathrm{Fe}, \mathrm{Mn}) \mathrm{Si}_{2}$ to $\beta-\mathrm{Al}_{5}(\mathrm{Fe}, \mathrm{Mn}) \mathrm{Si}$ below $610{ }^{\circ} \mathrm{C}$ occurred at room temperature in the high purity graphite crucible. Since the melt's cooling rate was accelerated due to the high thermal conductivity of the graphite crucible, the conversion of $\delta-\mathrm{Al}_{4}(\mathrm{Fe}, \mathrm{Mn})$ $\mathrm{Si}_{2}$ to $\beta-\mathrm{Al}_{5}(\mathrm{Fe}, \mathrm{Mn}) \mathrm{Si}$ cannot be completed, and some of the $\delta-\mathrm{Al}_{4}(\mathrm{Fe}, \mathrm{Mn}) \mathrm{Si}_{2}$ phase remained in the solidified microstructure. Therefore, the diffraction peaks of the three compounds can all be observed in the XRD spectra of CS-cast A1 alloy samples (Figure 5a). Then the remaining liquid phase solidified at its eutectic temperature, and Chinese script-shaped or fishbone-shaped $\alpha-\mathrm{Al}_{15}(\mathrm{Fe}, \mathrm{Mn})_{3} \mathrm{Si}_{2}$ would then have been crystallised in a quaternary eutectic reaction. In reality, few eutectic $\alpha-\mathrm{Al}_{15}(\mathrm{Fe}, \mathrm{Mn})_{3} \mathrm{Si}_{2}$ phases formed below the eutectic temperature because the Mn content added to the alloy was low.

When the $\mathrm{Mn} / \mathrm{Fe}$ ratio was 0.70 , acicular Fe phases cannot be observed in the microstructure of A2 alloy (see Figures $4 \mathrm{~b}$ and $6 \mathrm{~b}$ ). Research by Huang et al. ${ }^{10}$ proved that phases of PSP, $\alpha-\mathrm{Al}, \beta-\mathrm{Al}_{5}(\mathrm{Fe}, \mathrm{Mn}) \mathrm{Si}, \delta-\mathrm{Al}_{4}(\mathrm{Fe}, \mathrm{Mn})$ $\mathrm{Si}_{2}$, and $\alpha-\mathrm{Al}_{15}(\mathrm{Fe}, \mathrm{Mn})_{3} \mathrm{Si}_{2}$ coexisted in the alloy in the solidification of hypereutectic Al-Si with added $\mathrm{Mn}$ and $\mathrm{Fe}$ elements such that $\mathrm{Mn} / \mathrm{Fe}=0.625$. Meanwhile, they pointed out that only an $\alpha-\mathrm{Al}_{15}(\mathrm{Fe}, \mathrm{Mn})_{3} \mathrm{Si}_{2}$ phase, as an intermetallic compound, was present at $\mathrm{Mn} / \mathrm{Fe}=1$. In addition, some researchers noted ${ }^{11}$ that, the formation of $\alpha-\mathrm{Al}_{15}(\mathrm{Fe}, \mathrm{Mn})_{3} \mathrm{Si}_{2}$ can be promoted by adding $\mathrm{Mn}$ : with increasing $\mathrm{Mn}$ content, the crystallisation temperature range of $\delta-\mathrm{Al}_{4}(\mathrm{Fe}, \mathrm{Mn}) \mathrm{Si}_{2}$ is narrowed, and the crystallisation temperature range of $\alpha-\mathrm{Al}_{15}(\mathrm{Fe}, \mathrm{Mn})_{3} \mathrm{Si}_{2}$ is broadened. The $\alpha-\mathrm{Al}_{15}(\mathrm{Fe}, \mathrm{Mn})_{3} \mathrm{Si}_{2}$ phase may be primary since plenty $\mathrm{Mn}$ and Fe were added to high $\mathrm{Si}$ alloys ${ }^{17}$.

During the CS casting process of A2 alloy at $\mathrm{Mn}$ / $\mathrm{Fe}=0.7$, PSPs and a small amount of $\delta-\mathrm{Al}_{4}(\mathrm{Fe}, \mathrm{Mn}) \mathrm{Si}_{2}$, firstly crystallised at higher temperatures: then a large amount of $\alpha-\mathrm{Al}_{15}(\mathrm{Fe}, \mathrm{Mn})_{3} \mathrm{Si}_{2}$ formed and the residual $\delta-\mathrm{Al}_{4}(\mathrm{Fe}, \mathrm{Mn}) \mathrm{Si}_{2}$ was transformed to $\beta-\mathrm{Al}_{5}(\mathrm{Fe}, \mathrm{Mn}) \mathrm{Si}$ at below $610{ }^{\circ} \mathrm{C}$. Although the diffraction peak of the acicular $\delta-\mathrm{Al}_{4}(\mathrm{Fe}, \mathrm{Mn}) \mathrm{Si}_{2}$ phase can be found in $\mathrm{A} 2$ alloy, it proved difficult to find in the microstructure due to its reduced nucleation site activity in the initial solidification stage. Moreover, $\delta-\mathrm{Al}_{4}(\mathrm{Fe}, \mathrm{Mn}) \mathrm{Si}_{2}$ phases were involved in the peritectic reaction forming the acicular $\beta-\mathrm{Al}_{5}(\mathrm{Fe}, \mathrm{Mn})$ Si phase below $610{ }^{\circ} \mathrm{C}$. Owing to the low amount of $\delta-\mathrm{Al}_{4}(\mathrm{Fe}, \mathrm{Mn}) \mathrm{Si}_{2}$ in the reaction, nearly no $\beta-\mathrm{Al}_{5}(\mathrm{Fe}, \mathrm{Mn})$ $\mathrm{Si}$ phases were induced. Then the remaining liquid phase solidified at its eutectic temperature, and many Chinese script-, or fishbone-shaped $\alpha-\mathrm{Al}_{15}(\mathrm{Fe}, \mathrm{Mn})_{3} \mathrm{Si}_{2}$ particles were precipitated in the ensuing quaternary eutectic reaction. Based on the above reasoning, it was concluded that at $\mathrm{Mn} / \mathrm{Fe}=0.70$, there were no obvious acicular $\mathrm{Fe}$ phases discernible, and the intermetallic compounds mainly comprised blocky and Chinese script-, or fishbone-shaped $\alpha-\mathrm{Al}_{15}(\mathrm{Fe}, \mathrm{Mn})_{3} \mathrm{Si}_{2}$ phases in the microstructure. 


\section{Conclusions}

- The slope angle of the upper steel plate is $30^{\circ}$, while that of the lower graphite plate is $50^{\circ}$. Besides, the effective length required of each plate is $0.3 \mathrm{~m}$, fine, regular-shaped PSPs can be obtained. In addition, acicular Fe phases, coarser fishbone-shaped $\alpha-\mathrm{Al}_{15}(\mathrm{Fe}, \mathrm{Mn})_{3} \mathrm{Si}_{2}$ phases, and eutectic $\mathrm{Si}$ can be refined by the CS process.

- The as-cast microstructure of the $\mathrm{A} 0$ alloy comprises grey PSPs $50 \mu \mathrm{m}$ in equivalent diameter, white $\alpha$-Al, black acicular Fe phases $100 \mu \mathrm{m}$ in length, and lamellar eutectic $\mathrm{Si}$. Without CS processing, acicular $\delta-\mathrm{Al}_{4}(\mathrm{Fe}, \mathrm{Mn}) \mathrm{Si}_{2}$ phase, $\beta-\mathrm{Al}_{5}(\mathrm{Fe}, \mathrm{Mn}) \mathrm{Si}$ phase, and coarser fishboneshaped $\alpha-\mathrm{Al}_{15}(\mathrm{Fe}, \mathrm{Mn})_{3} \mathrm{Si}_{2}$ phase coexist in the solidification microstructure of the alloy with an $\mathrm{Mn} / \mathrm{Fe}$ ratio 0.52. Without CS-processing, acicular Fe phases can be observed and only coarser fishbone-shaped and fine $\alpha-\mathrm{Al}_{15}(\mathrm{Fe}, \mathrm{Mn})_{3} \mathrm{Si}_{2}$ phases are seen in the microstructure of the alloy with $1.35 \% \mathrm{Mn}$ content.

- Through the analysis of the SADPs, the lattice structures of acicular $\delta-\mathrm{Al}_{4}(\mathrm{Fe}, \mathrm{Mn}) \mathrm{Si}_{2}$ and $\alpha-\mathrm{Al}_{15}(\mathrm{Fe}, \mathrm{Mn})_{3} \mathrm{Si}_{2}$ phases are identified with tetragonal structure and body centre cubic, respectively.

\section{References}

1. Al-Helal K, Stone IC and Fan Z. Simultaneous Primary Si Refinement and Eutectic Modification in Hypereutectic Al-Si Alloys. Transactions of the Indian Institute of Metals. 2012; 65(6):663-667. http://dx.doi.org/10.1007/s12666-012-0171-4

2. Zuo M, Zhao D, Teng X, Geng H and Zhang Z. Effect of P and Sr complex modification on Si phase in hypereutectic Al-30Si alloys. Materials and Design. 2013; 47:857-864. http://dx.doi. org/10.1016/j.matdes.2012.12.054

3. Tang D, Mao X, Zhang J, Xu Z and Shen Y. A green and permanent modificant for hypereutectic Al-Si alloys. Foundry. 2002; 51:652-653.

4. Kapranos P, Kirkwood DH, Atkinson HV, Rheinländer JT, Bentzen JJ, Toft PT et al. Thixoforming of an automotive part in A390 hypereutectic Al-Si alloy. Journal of Materials Processing Technology. 2003; 135:271-277. http://dx.doi. org/10.1016/S0924-0136(02)00857-9

5. Birol Y. Cooling slope casting and thixoforming of hypereutectic A390 alloy. Journal of Materials Processing Technology. 2008; 207:200-203. http://dx.doi.org/10.1016/j. jmatprotec.2007.12.071

6. Chol YS, Lee JS, Kim WT and Ra HY. Solidification behavior of $\mathrm{Al}-\mathrm{Si}-\mathrm{Fe}$ alloys and phase transformation of metastable intermetallic compound by heat treatment. Journal of Materials Science. 1999; 34:2163-2168. http://dx.doi. org/10.1023/A:1004584415196

7. Kim HY, Park TY, Han SW and Lee HM. Effects of Mn on the crystal structure of ?-Al(Mn, Fe)Si particles in A356 alloys. Journal of Crystal Growth. 2006; 291:207-211. http://dx.doi. org/10.1016/j.jcrysgro.2006.02.006

8. Warmuzek M, Sieniawski J, Wicher K and Mrowka G. The study of the distribution of the transition metals and Si during primary precipitation of the intermetallic phases in Al-Mn-Si alloys. Journal of Materials Processing Technology. 2006; 175:421-426. http://dx.doi.org/10.1016/j. jmatprotec.2005.04.005
- As $\mathrm{Mn} / \mathrm{Fe}$ ratio is 0 , acicular $\delta-\mathrm{Al}_{4} \mathrm{FeSi}_{2}$ phases, as a main intermetallic compound, are present in the CS-cast microstructure of the A0 alloy. With CS-processing, the alloy with an $\mathrm{Mn} / \mathrm{Fe}$ ratio of 0.52 has the $\delta-\mathrm{Al}_{4}(\mathrm{Fe}, \mathrm{Mn}) \mathrm{Si}_{2}$ phases as its main acicular Fe-rich phase, and the coarser fishbone-shaped $\alpha-\mathrm{Al}_{15}(\mathrm{Fe}, \mathrm{Mn})_{3} \mathrm{Si}_{2}$ phases are observed in its microstructure. As the $\mathrm{Mn} / \mathrm{Fe}$ ratio increased to 0.7 , blocky and Chinese script-, or fishbone-shaped compounds as the main intermetallic compounds found in the microstructure of the A2 alloy.

\section{Acknowledgements}

The authors acknowledge funding for this research from National Science Foundation of China (51261011), Science and Technology Project Foundation of Yunnan Province of China (2010DH025), and Personnel Training Project of Yunnan Province of China (2009CI024). This work is supported by the Institute of Advanced Materials Processing, Kunming University of Science and Technology, Kunming, China.

9. Wu G, Zhu Y and Ding W. Effect of Mn on the Fe phases of B319 aluminum alloy in LFC. Foundry. 2002; 51:85-88.

10. Huang HJ, Cai YH, Cui H, Huang JF, He JP and Zhang JS. Influence of Mn addition on microstructure and phase formation of spray-deposited Al-25Si-xFe-yMn alloy. Materials Science and Engineering A. 2009; 502:118-125. http://dx.doi.org/10.1016/j.msea.2008.10.005

11. Wang F, Zhang J, Xiong B and Zhang Y. Effect of Fe and $\mathrm{Mn}$ addition on microstructure and mechanical properties of spray-deposited Al-20Si-3Cu-1Mg alloy. Materials characterization. 2009; 60:384-388. http://dx.doi.org/10.1016/j. matchar.2008.10.011

12. Lin $\mathrm{C}, \mathrm{Wu} \mathrm{S}$, Lü $\mathrm{S}, \mathrm{An} \mathrm{P}$ and Wan L. Effects of ultrasonic vibration and manganese on microstructure and mechanical properties of hypereutectic Al-Si alloys with $2 \% \mathrm{Fe}$. Intermetallics. 2013; 32:176-183. http://dx.doi.org/10.1016/j. intermet.2012.09.001

13. Umezawa O, Nakamoto M, Osawa Y, Suzuki K and Kumai S. Microstructural Refinement of Hyper-Eutectic Al-Si-FeMn Cast Alloys to Produce a Recyclable Wrought Material. Materials Transactions. 2005; 46(12):2609-2615.

14. Gowri S and Samuel FH. Effect of alloying elements on the solidification characteristics and microstructure of $\mathrm{Al}-\mathrm{Si}-\mathrm{Cu}-$ Mg- Fe 380 alloy. Metallurgical and Materials Transactions A. 1994; 25:437-438. 10.1007/BF02647989 http://dx.doi. org/10.1007/BF02647989

15. Vadim S.ZZlotorevsky, Nikolai A. Belove, Michael V. Glazoff. Casting Aluminum Alloys. Elsevier Ltd.; 2007. p. 48.

16. Zhong G, Wu S, AN P, Mao Y and Li S. Microstructure and properties of high silicon aluminum alloy with $2 \%$ Fe prepared by rheo-casting. Transactions of Nonferrous Metals Society of China. 2010; 20:1603-1607. http://dx.doi.org/10.1016/S10036326(09)60346-0

17. Shabestari SG. The effect of iron and manganese on the formation of intermetallic compounds in aluminum-silicon alloys. Materials Science and Engineering A. 2004; 383:289-298. 